\title{
Erythrocytapheresis: Do Not Forget a Useful Therapy!
}

\author{
Heidrun Ullrich ${ }^{a}$ Roland Fischer ${ }^{b, c}$ Regine Grosse ${ }^{b} \quad$ Uwe Kordes $^{b} \quad$ Claudia Schubert $^{a}$ \\ Bettina Altstadt ${ }^{\mathrm{a}}$ Georges Andreu ${ }^{\mathrm{d}}$ \\ ${ }^{a}$ Department of Transfusion Medicine, \\ ${ }^{b}$ Department of Paediatric Haematology and Oncology, University Medical Center Hamburg-Eppendorf, Hamburg, Germany \\ ${ }^{c}$ Children's Hospital \& Research Center Oakland, Oakland, CA, USA \\ dInstitut National de la Transfusion Sanguine, Paris Cedex, France
}

\section{Key Words}

Erythrocytapheresis - Red blood cell exchange .

Sickle cell disease . Exchange transfusion

\section{Summary}

In patients with pathologically altered erythrocytes, red blood cell exchange is a very efficient therapeutic measure without important side effects. With increasing migration more patients with e.g. severe malaria or sickle cell anemia have to be treated. In minor or bidirectional ABO-mismatched stem cell transplantations after reduced intensity conditioning, hemolysis can be prevented by prophylactic erythrocytapheresis. Other rare indications for red blood cell exchange are advanced erythropoietic protoporphyria and babesiosis. Sickle cell anemia can be treated with hydroxyurea. Transfusions are administered when necessary, but this results in iron overload in the long term. An expensive but safe and very efficient treatment alternative is red blood cell exchange. In cases with stroke, acute chest syndrome and other severe complications, erythrocytapheresis reproducibly breaks the vicious circle of sickling and increasing oxygen deficiency. At the same time one can aim at an exact end hematocrit. In severe malaria, erythrocytapheresis both reduces parasite load to the designated extent and reconstitutes reduced oxygen transport capacity without serious adverse effects. Here we describe our experience of erythrocytapheresis in long-term prophylaxis of complications in sickle cell anemia and sickle cell thalassemia patients. The documentation of improved iron balance was carried out by liver susceptometry.

\author{
Schlüsselwörter \\ Erythrozytapherese - Austauschtransfusion . \\ Sichelzellanämie $\cdot$ Erythrozytenaustausch
}

\section{Zusammenfassung}

Die Erythrozytapherese ist eine sehr effiziente therapeutische Maßnahme bei Patienten mit klinischen Problemen durch pathologisch veränderte Erythrozyten. Durch zunehmende Migration und Reisen wird es immer häufiger nötig, schwere Malaria sowie Patienten mit Sichelzellanämie und Thalassämie zu behandeln. Sichelzellanämie wird bei Bedarf mit Hydroxyurea behandelt, um die Hämoglobin-F-Konzentration im Blut zu steigern. Transfusionen werden bei Hypoxie und schwerer Anämie verabreicht, aber dadurch entsteht eine Eisenüberladung. In der Zulassung befindliche orale Chelatbildner sollen dieses Problem verringern. Eine teure, aber nebenwirkungsarme und sichere Alternative ist die Erythrozytapherese. Bei Patienten mit Schlaganfall, akutem Thoraxsyndrom und anderen schweren Sichelzellkomplikationen führt der Erythrozytenaustausch zu einer schnellen und reproduzierbaren Besserung; der Teufelskreis zwischen Sichelzellbildung, Minderdurchblutung und Hypoxämie wird gebrochen und der gewünschte Hämatokrit kann erzielt werden. Bei den meisten Malariapatienten ist medikamentöse Therapie ausreichend, aber bei starkem Parasitenbefall können Hämolyse und Anämie prompt und nebenwirkungsarm durch Erythrozytenaustausch behoben werden; die Menge befallener Erythrozyten wird in den angepeilten Bereich bewegt und der Patient wird einer Medikamententherapie zugänglich. Wir beschreiben unsere Erfahrungen in der Sekundärprophylaxe von Komplikationen bei Sichelzellanämie und Sichelzellthalassämie. Der Schutz vor Eisenüberladung wurde mit Hilfe der Leber-Biosuszeptometrie dokumentiert. 


\section{Introduction}

Erythrocytapheresis, also referred to as red blood cell exchange, is a procedure rarely thought of. The use of modern cell separators, the introduction of leukodepletion in blood products, and the increasing safety of red blood cell concentrates have made this treatment modality very effective, comfortable and safe.

The increasing number of persons with African, Asian and Mediterranean origin in our country has led to an increased incidence of sickle cell anemia and sickle cell thalassemia patients. The rising number of trips to malaria regions obliges to treat malaria regularly.

Repetitive transfusions cause iron overload. This has so far been treated by subcutaneous application of chelators with very poor compliance. The advent of oral chelators mitigates this problem. However, there still are indications where the increased blood viscosity and insufficient relative reduction of pathologically altered red blood cells needs better and faster treatment [1-3].

Sickle cell anemia is caused by homozygous glu6val (hemoglobin $\mathrm{S} ; \mathrm{HbS}$ ) mutation. The disorder is recessively inheritable, heterozygotes for glu6val and glu6lys mutations (hemoglobin SC) suffer from sickle cell disease, too. Similar clinical problems are found in patients with sickle-beta-thalassemia. The course of these defects is highly variable, and progress in predicting complications is under progress.

Children who have suffered from one ischemic cerebrovascular accident have a very high risk of relapse that can be significantly lowered by transfusions [4-12]. But transfusion-induced increase in blood viscosity can aggravate perfusion problems. Erythrocytapheresis is a very safe and efficient way of both reducing blood viscosity and improving oxygen delivery to the tissue $[1,2]$.

Hemotherapy for sickle cell disease complications is divided into treatment of acute crises such as stroke and acute chest syndrome and prevention of complications and relapses.

In crises hemoglobin polymerization causes sickling of red blood cells and leads to vasoocclusion and perfusion problems. Inflammation and increased cell adhesion to the endothelium adds to this problem. Adhesion of altered erythrocytes is caused by the damage of red blood cells from polymerized hemoglobin $\mathrm{S}$ in addition to externalization of phosphatidylserine onto the outer leaflet of the cell membrane. The importance of the 10-fold increase in blood viscosity by sickling red blood cells is often forgotten; this increase is the more severe the faster deoxygenation happens. Increased leukocyte and platelet adhesion to the endothelium aggravates perfusion problems. The reduced blood flow speed in the occluded vasculature leads to a vicious circle of sickling, increased adhesion and decreased oxygenation. Mediators of inflammation and adhesion molecules (TNF- $\alpha$, IFN, IL-1 $\beta$, vascular endothelial growth factor, thrombin, histamine, platelet activating factor) enhance endothelial adhesivity. NO released from endothelial cells for vasodilatation is antagonized by free hemoglobin from hemolysed erythrocytes. Liberation of arginase from disrupted erythrocytes and reactive oxygen radicals lead to further reduction of NO.

The STOP study [6] clearly demonstrated that increased blood flow velocities as detected by Doppler ultrasound could predict risk of stroke and that consecutive transfusion can prevent this. If the transfusions are stopped, the patients are at high risk of relapse [11]. Patients who have already suffered any of the severe sickle cell disease-related complications (stroke, acute chest syndrome, pain crises, upper quadrant syndrome or priapism) are at high risk of relapse of the same complication [3]. Thus secondary prophylaxis of these sickle cell disease complications is an important goal. In patients with high blood viscosity and severe perfusion problems, transfusions are insufficient because they further increase viscosity and iron overload on the long run. For these patients, red blood cell exchange with immediate improvement of oxygen transport is the only treatment option.

Ferritin is a poor indicator of iron overload because it is highly influenced by inflammation [13]. Measuring liver iron concentration (LIC) best monitors iron overload. This can be done invasively by liver biopsy or better by biosusceptometry. Noninvasive biosusceptometry is carried out to control sickle cell disease patients who are either transfused or receive red blood cell exchange.

\section{Material and Methods}

\section{Erythrocytapheresis Technique}

We performed erythrocytapheresis using the Cobe Spectra cell separator with the standard erythrocytapheresis program in the older patients with veno-venous access; in small children blood was given back via port. At first an ACD-to-whole blood ratio of 1:14 was used, later we gave $\mathrm{ACD}$ at a rate of 1:17 with the maximally tolerated blood flow.

\section{Red Cells Used}

Red blood cell concentrates were matched to the most important blood group systems (ABO, Rhesus, Kell, Duffy and if possible Kidd), and prestorage leukodepleted concentrates maximally 5 days old were used. So far none of our patients developed alloantibodies to red blood cells. No infections related to red blood cells were observed [14]. We aimed at increasing the hematocrit by maximally 0.02 in anemic patients. Exchange transfusion of about one patient's blood volume and reduction of $\mathrm{HbS}$ to values under $30 \%$ were aspired.

\section{Side Effects}

During regular apheresis therapy patients did not need additional transfusions. No serious side effects of erythrocytaphereses were seen; only venous access problems and in one 
Fig. 1. Serum ferritin under continuous erythrocytapheresis treatment in 4 patients with sickle cell disease.

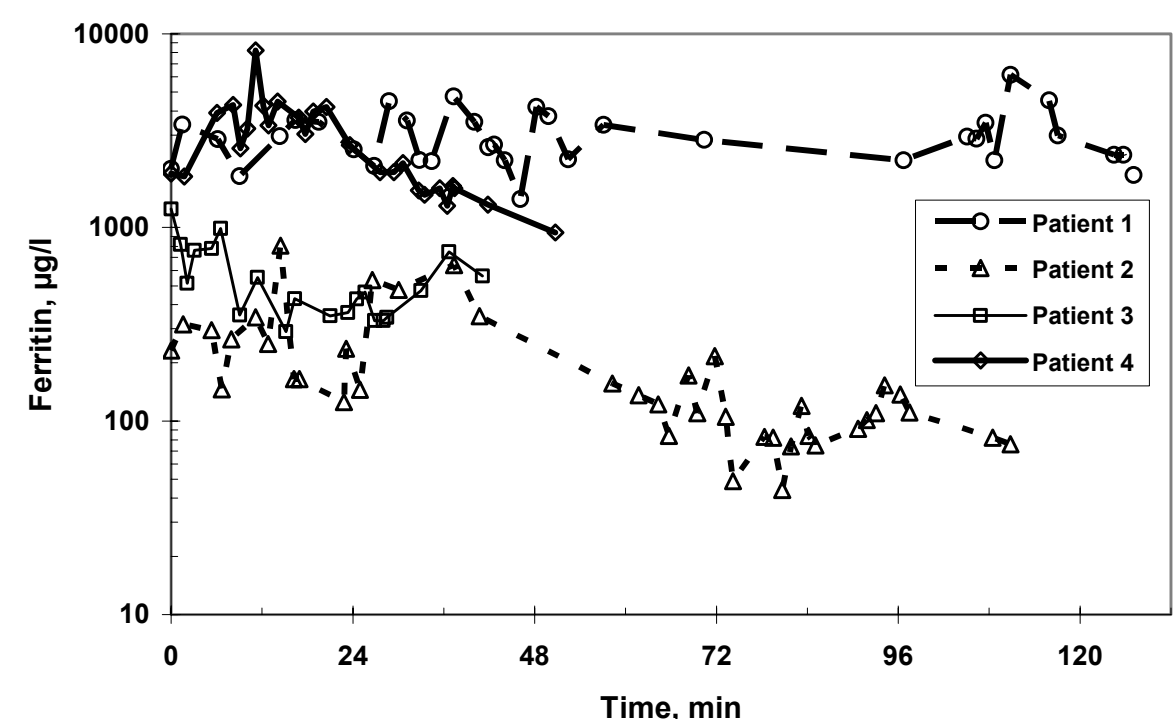

patient mild citrate reactions were noted. The first was overcome by catheter implantation and the latter by reduction of the citrate rate to $1: 17$ and calcium substitution into the return line. Both stroke patients recovered excellently and did not suffer from any relapse in spite of high risk. Iron overload was tolerable. The one patient with many transfusions before red cell aphereses had subcutaneous chelation therapy, but she abandoned that because of side effects. With the availability of oral chelators, this should be started again in spite of her compliance. The two patients with pain crises showed clinical complications every time they exceeded routine apheresis intervals because $\mathrm{HbS}$ rose too high.

\section{Results}

\section{Patient 1}

Patient 1 is a young woman born in 1983 in Africa. She has always been transfusion-dependent. At first treatment at our hospital in July 1990 she suffered from a hematocrit of 15\%, hepatitis $\mathrm{C}$ as well as a lack of folic acid and vitamin B12. In June and November 1991 she had two pain crises. In August 1992 she suffered from vascular obliterations and received two red blood cell concentrates. In the following year a program of 6-12 weekly transfusions was instituted. In February 1995 epistaxis was observed, since September 1995 red cell exchanges were carried out every 6-12 weeks and continued until 2000. In 1996 subcutaneous Desferal was started to reduce iron overload. Two years after the start of chelation sudden hearing loss occurred, probably as a side effect of this treatment, and Desferal was stopped. In 2000 hydroxyurea was started and aphereses were stopped, but the patient suffered from further pain crises. In 2001 she received red cell transfusions during pregnancy. In February 2002 erythrocytaphereses were started again and continued until today. So far she has undergone 62 red blood cell aphereses. The patient's compliance is variable. In the course of the last year she suffered from two pain crises when intervals between aphereses became too long. Ferritin as an inflammatory protein rose and decreased again as the hepatitis became clinically more stable. Her ferritin level as a marker of inflammation was very high and extremely variable at periods with greater hepatitis activity (fig. 1). Liver susceptometry showed increased LIC, but less than would be expected with blood transfusions instead of red cell exchanges (fig. 2). She always has signs of hemolysis and inflammation such as elevated reticulocytes, reduced haptoglobin, and high LDH and leukocyte levels. In spite of these symptoms, iron overload and deterioration of complications such as pain crises and osteonecrosis could be delayed. Iron overload is clearly less problematic than in simple blood transfusion. Even hemolysis of sickle cells was mitigated.

\section{Patient 2}

Patient 2, a young man born in 1987, suffers from combined sickle cell-beta thalassemia and has been symptomatic since his 4 th year of life. Until the age of 9 years he had received 4 red blood cell concentrates. In February 1998, at an age of 10 years, he presented in our hospital with a pain crisis and received 2 red blood cell concentrates. In April of the same year automated red blood cell exchanges were started and continued until now at 4-weekly intervals. The patient's compliance has decreased during the course of adolescence, and every time the intervals between blood exchanges became too long the patient suffered from pain crises that lasted for several days, improving only slowly after erythrocytapheresis. Overall he was treated with 82 red blood cell aphereses so far. Levels of ferritin, an acute phase protein, first rose, but decreased during adolescence, perhaps reflecting emptying iron stores due to growth. LIC was not as high as in comparable patients with transfusions only, and the number of complications could be kept low by repeating aphereses at short intervals. LIC was 
Fig. 2. a LIC by SQUID biosusceptometry under continuous erythrocytapheresis treatment in 4 patients with sickle cell disease.

Median LIC for SCD under blood transfusion treatment according to [15]. b Ferritin-to-LIC ratio under continuous erythrocytapheresis treatment in 4 patients with sickle cell disease. Expected interquartile range for SCD under blood transfusion treatment according to [15].
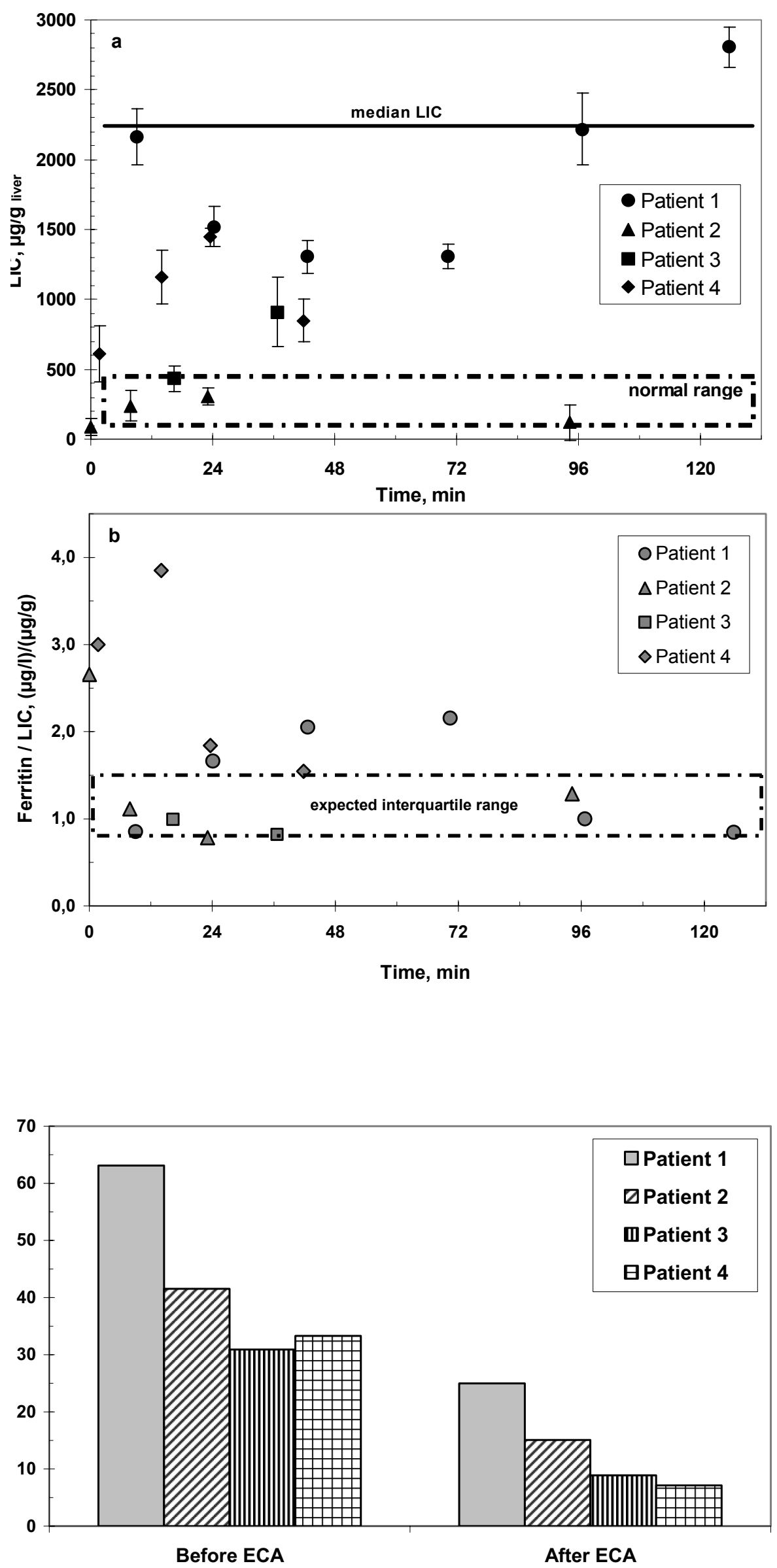

Transfus Med Hemother 2008;35:24-30 
highest in 2000, now it has become normal with elevated ferritin levels. LIC and ferritin levels are shown in figures 1 and 2 . The HbS levels have been kept in a tolerable range as shown in figure 3. In 2004 MRT was carried out because of continuing pains in the legs. Traces of deep vein thromboses and aseptic bone necroses in both acetabuli and femora were seen. Clearly, without aphereses this patient would have many more clinical complications and iron overload due to the necessary transfusions.

\section{Patient 3}

Patient 3 was born in December 1998. Sickle cell disease was diagnosed in 2001. He suffered from stroke in January 2003 ensued by left-sided hemiparesis and convulsive versive seizures that had to be treated with carbamazepin. Hemosiderosis at that time was quantified by liver susceptometry (fig. 2). The left leg was operated on several times to alleviate spastic paresis consequences. Meanwhile, the patient has learned to walk again in spite of his overweight $(54 \mathrm{~kg}, 141$ $\mathrm{cm})$. Four months after the stroke a 4- to 6-weekly red cell exchange program was started in May 2003 as secondary stroke prophylaxis. Due to poor venous access a port-a catheter was implanted into the left jugular vein in August of the same year. Up to now 42 erythrocytaphereses were carried out every 4-6 weeks without side effects. Hemosiderosis did not progress. Cerebral blood flow as assessed by transcranial Doppler sonography was normal in posterior cerebral arteries; the other arteries were not evaluable. Residues of the stroke are seen in the EEG. LIC has increased from $432 \mathrm{mg} / \mathrm{g}$ liver in March 2005 to $910 \mathrm{mg} / \mathrm{g}$ liver in November 2006, ferritin is 561 $\mathrm{mg} / \mathrm{l}$. Overall the iron load is tolerable as shown in figures 1 and 2. No erythrocytapheresis complications were seen in this high-risk patient, and even iron chelation therapy has not become necessary.

\section{Patient 4}

Patient 4 was born in February 1999, and homozygous sickle cell anemia was diagnosed in June 2002 during pneumococcal sepsis. In April 2002 he suffered from a stroke and recovered quite well. Transcranial Doppler sonography was nearly normal again in December 2002, showed further improvement in February 2005 and normal values since March 2006. MRT shows defect healing in the left fronto-parietal region. Since July 2003 he received regular red blood cell aphereses every 4-5 weeks. Ferritin values varied highly and are now in a tolerable range (fig. 1). LIC is still in the range where no chelation therapy is necessary. No clinically relevant problems occurred. All 46 erythrocytaphereses carried out so far were tolerated well. Since 2004 he complained of abdominal pain and flatulence at the end of each apheresis procedure. As a consequence we reduced the citrate ratio from 1:13 to $1: 17$ and substituted calcium during every treatment. After that no more side effects have been observed. At 9 years of age he is $136 \mathrm{~cm}$ tall, with a weight of 56 $\mathrm{kg}$ and a head circumference of $57.8 \mathrm{~cm}$.

\section{Discussion}

Problems in sickle cell disease arise from deficiencies in oxygen delivery to the tissue due to erythrocyte deformation, hemolysis, and inflammation. Increase in blood viscosity leads to perfusion problems, mainly in large vessels. Hemolysis adds to this problem by scavenging of the vasodilator NO released by endothelial cells. Inflammation and increased cell adhesion of erythrocytes as well as leukocytes and platelets contribute to vasoocclusion, especially in small vessels, during crises.

Blood viscosity of oxygenated sickle cell blood is 1.5 -fold that of normal blood, but increases to 10-fold upon deoxygenation. This increase is the higher the faster the deoxygenation occurs. High hematocrit contributes to increasing viscosity. Transfusion alone further increases blood viscosity and limits relative reduction of $\mathrm{HbS}$.

Blood usually is transfused at a speed of about $2 \mathrm{~h}$ per red cell concentrate. Elevating hemoglobin above $10 \mathrm{mg} / \mathrm{dl}$ often causes a too steep increase in blood viscosity [3].

Moreover, red cell concentrates are usually transfused slowly, and a standard transfusion of two units takes at least $3 \mathrm{~h}$. This limitation is easily overcome by apheresis, up to $10 \mathrm{red}$ blood cell concentrates can easily be exchanged in less than $3 \mathrm{~h}$ without relevant side effects, thus giving the possibility of immediate improvement in case of crisis and providing a more comfortable procedure in patients treated prophylactically.

Erythrocytapheresis is the only way to reduce quickly and in a comfortable way for the patient the concentration of HbScontaining red cells.

As shown in figure 3, in our patients an immediate reduction of $\mathrm{HbS}$ below $30 \%$ as postulated by Pegelow et al. [12] could be achieved by erthrocytapheresis. The major advantages of erythrocytapheresis are the decrease in blood viscosity in parallel to the increase in oxygen transport capacity. At the same time defective red blood cells are replaced; thus hemolysis and ensuing inflammation, cell adhesion and NO antagonism are reduced [16].

During our prophylactic erythrocytaphereses we aimed at keeping the hematocrit rather stable and tried not to increase hemoglobin values much above the levels the patients were adapted to, usually ranging from 0.30 and 0.35 . This relatively low hematocrit contributes to prevent risks related to high viscosity. Actually, our targets for prophylactic erythrocytapheresis are similar to those expected in case of stroke, acute chest syndrome and acute multiorgan damage syndrome, where a decrease of hematocrit to 0.3 and an immediate reduction of HbS red blood cells should be aspired.

Despite the use of a great number of red cell concentrates, a long-term erythrocytapheresis program is extremely useful to minimize iron overload although it has little or no effect on a pre-existing iron overload related to a conventional transfusion program. At the same time free hemoglobin and NO scavenging are reduced [16], restoring normal vasodilatation and endothelial function.
28

Transfus Med Hemother 2008;35:24-30
Ullrich/Fischer/Grosse/Kordes/Schubert/ Altstadt/Andreu 
Our secondary prophylaxis patients are all at highest risk to develop severe sickle cell disease complications. Since they are treated by erythrocytaphereses, they have not suffered from severe or irreversible problems. The young stroke patients have made fair progress in improving their stroke complications: both have started to grow normally, which can often be a problem in this patient group with low hemoglobin levels [17]. Transcranial Doppler blood flow velocities in the evaluable arteries are normal by now in both boys. The two patients with pain crises regularly suffer from relapse when intervals between treatment sessions were extended too much and improve within days after red blood cell apheresis. Biosusceptometry shows in all patients an iron overload that is much lower than in transfused patients. They are all adequately treated with a good quality of life and do not need chelators even after such a long disease duration.

Another indication for prophylactic red blood cell exchange is the prevention of severe immune hemolysis in minor and bidirectionally ABO-mismatched allogeneic peripheral blood progenitor cell transplantation after reduced intensity conditioning. Incidence and severity of this life-threatening complication can be reduced by prophylactic apheresis [18].

Erythrocytapheresis is helpful for the treatment of various crises. It leads to immediate improvement of symptoms in severe malaria and babesiosis $[19,20]$ and has also been successfully carried out for the prevention of alloimmunization against D+ antigen in combination with intravenous immunoglobulin [21]. Autoimmune hemolytic anemia is caused by circulating autoantibodies against red blood cells. Acute symptoms can be relieved by exchanging incompatible autologous red blood cells against compatible donor erythrocytes [22].
In erythropoietic protoporphyria ferrochelatase, the final enzyme in heme formation, is lacking. So protoporphyrin is deposited in the tissue, and blood protoporphyrin levels are elevated. Plasma exchange can reduce protoporphyrin levels, but red blood cell exchange has been reported to be more efficient because its concentration is severalfold higher inside red blood cells [23].

Preoperative red cell exchange may also be useful in patients with severe sickle cell disease to prevent complications from operation or anesthesia [24].

Nowadays, the decision to include a patient with sickle cell disease in an erythrocytapheresis program is based mainly on the previous occurrence of a major complication such as stroke, acute chest syndrome, or multi-organ damage syndrome. However, there is a great amount of recent works trying to identify risk factors of such complications in patients with sickle cell disease, e.g. intensity of hemolysis is correlated to leg ulcers [25]. Factor XIII, factor V Leiden and fibroblast growth factor 2 disturbances can all add to sickle cell complications.

Since 2004 various articles have related additional genetic risk factors and sickle cell complications: TNF- $\alpha$ promoter polymorphisms, Il-4 receptor and adrenergic $\beta 2$ receptor are related to large vessel stroke, and VCAM1 and low density lipoprotein receptor polymorphisms show correlation to small vessel stroke [27]. $\alpha$-Klotho, annexin-2 and bone morphogenic protein 6 are involved in vascular disease as well as bone calcium regulation and metabolism and bone morphogenesis and have also been shown to be risk factors for sickle cell disease complications [26-33].

Therefore, it is likely that in the future erythrocytapheresis programs will be more often initiated as a primary prophylactic intervention.

\section{References}

1 Thurston GB, Henderson NM, Jeng M: Effects of erythrocytapheresis transfusion on the viscoelasticity of sickle cell blood. Clin Hemorheol Microcirc 2004;30:83-97.

2 Adams HP Jr, Adams RJ, Brott T, del Zoppo GJ, Furlan A, Goldstein LB, Grubb RL, Higashida R, Kidwell C, Kwiatkowski TG, Marler JR, Hademenos GJ: Guidelines for the early management of patients with ischemic stroke: a scientific statement from the Stroke Council of the American Stroke Association. Stroke 2003;34:1056-1083.

3 Swerdlow PS: Red cell exchange in sickle cell disease. Hematology Am Soc Hematol Educ Program 2006;:48-53.

4 Adams RJ, Brambilla D: Discontinuing prophylactic transfusions used to prevent stroke in sickle cell disease. N Engl J Med 2005;353:2769-2778.

$\checkmark 5$ Adams RJ: Lessons from the Stroke Prevention Trial in Sickle Cell Anemia (STOP) study. J Child Neurol 2000;15:344-349.

6 Adams RJ, McKie VC, Hsu L, Files B, Vichinsky E, Pegelow C, Abboud M, Gallagher D, Kutlar A, Nichols FT, Bonds DR, Brambilla D: Prevention of a first stroke by transfusions in children with sickle cell anemia and abnormal results on transcranial Doppler ultrasonography. N Engl J Med 1998;339: 5-11.
7 Adams RJ, Ohene-Frempong K, Wang W: Sickle cell and the brain. Hematology Am Soc Hematol Educ Program 2001; 31-46.

8 Adams RJ, Pavlakis S, Roach ES: Sickle cell disease and stroke: primary prevention and transcranial Doppler. Ann Neurol 2003;54:559-563.

9 Adams RJ, Brambilla DJ, Granger S, Gallagher D, Vichinsky E, Abboud MR, Pegelow CH, Woods G, Rohde EM, Nichols FT, Jones A, Luden JP, Bowman L, Hagner S, Morales KH, Roach ES: Stroke and conversion to high risk in children screened with transcranial Doppler ultrasound during the STOP study. Blood 2004;103:3689-3694.

10 Adams RJ: Stroke prevention and treatment in sickle cell disease. Arch Neurol 2001;58:565-568.

11 Adams RJ, McKie VC, Brambilla D, Carl E, Gallagher D, Nichols FT, Roach S, Abboud M, Berman B, Driscoll C, Files B, Hsu L, Hurlet A, Miller S, Olivieri N, Pegelow C, Scher C, Vichinsky E, Wang W, Woods G, Kutlar A, Wright E, Hagner S, Tighe F, Waclawiw MA: Stroke prevention trial in sickle cell anemia. Control Clin Trials 1998;19:110-129.
12 Pegelow CH, Adams RJ, McKie V, Abboud M, Berman B, Miller ST, Olivieri N, Vichinsky E, Wang $\mathrm{W}$, Brambilla D: Risk of recurrent stroke in patients with sickle cell disease treated with erythrocyte transfusions. J Pediatr 1995;126:896-899.

13 Harmatz P, Butensky E, Quirolo K, Williams R, Ferrell L, Moyer T, Golden D, Neumayr L, Vichinsky E: Severity of iron overload in patients with sickle cell disease receiving chronic red blood cell transfusion therapy. Blood 2000;96:76-79.

14 Sarode R, Altuntas F: Blood bank issues associated with red cell exchanges in sickle cell disease. J Clin Apher 2006;21:271-273.

15 Pakbaz Z, Fischer R, Fung E, Nielsen P, Harmatz P, Vichinsky E: Serum ferritin underestimates liver iron concentration in transfusion independent thalassemia patients as compared to regularly transfused thalassemia and sickle cell patients. Pediatr Blood Cancer 2007;49:329-332.

16 Lezcano NE, Odo N, Kutlar A, Brambilla D, Adams RJ: Regular transfusion lowers plasma free hemoglobin in children with sickle-cell disease at risk for stroke. Stroke 2006;37:1424-1426. 
17 Wang WC, Morales KH, Scher CD, Styles L, Olivieri N, Adams R, Brambilla D: Effect of longterm transfusion on growth in children with sickle cell anemia: results of the STOP trial. J Pediatr 2005;147:244-247.

18 Worel N, Greinix HT, Supper V, Leitner G, Mitterbauer M, Rabitsch W, Fischer G, Rosenmayr A, Höcker P, Kalhs P: Prophylactic red blood cell exchange for prevention of severe immune hemolysis in minor ABO-mismatched allogeneic peripheral blood progenitor cell transplantation after reducedintensity conditioning. Transfusion 2007;47:14941502.

19 Riddle MS, Jackson JL, Sanders JW, Blazes DL: Exchange transfusion as an adjunct therapy in severe Plasmodium falciparum malaria: a meta-analysis. Clin Infect Dis 2002;34:1192-1198.

20 Dorman SE, Cannon ME, Telford SR III, Frank KM, Churchill WH: Fulminant babesiosis treated with clindamycin, quinine, and whole-blood exchange transfusion. Transfusion 2000;40:375-380.

-21 Nester TA, Rumsey DM, Howell CC, Gilligan DM, Drachman JG, Maier RV, Kyles DM, Matthews DC, Pendergrass TW: Prevention of immunization to D+ red blood cells with red blood cell exchange and intravenous $\mathrm{Rh}$ immune globulin. Transfusion 2004;44:1720-1723.
22 Johnson ST, McFarland JG, Kelly KJ, Casper JT, Gottschall JL: Transfusion support with RBCs from an Mk homozygote in a case of autoimmune hemolytic anemia following diphtheria-pertussistetanus vaccination. Transfusion 2002;42:567-571.

23 Eichbaum QG, Dzik WH, Chung RT, Szczepiorkowski ZM: Red blood cell exchange transfusion in two patients with advanced erythropoietic protoporphyria. Transfusion 2005;45:208-213.

24 Buck J, Casbard A, Llewelyn C, Johnson T, Davies S, Williamson L: Preoperative transfusion in sickle cell disease: a survey of practice in England. Eur J Haematol 2005;75:14-21.

25 Nolan VG, Adewoye A, Baldwin C, Wang L, Ma Q, Wyszynski DF, Farrell JJ, Sebastiani P, Farrer LA, Steinberg MH: Sickle cell leg ulcers: associations with haemolysis and SNPs in Klotho, TEK and genes of the TGF-beta/BMP pathway. Br J Haematol 2006;133:570-578.

26. Hoppe C, Klitz W, D'Harlingue K, Cheng S, Grow M, Steiner L, Noble J, Adams R, Styles L: Confirmation of an association between the TNF(-308) promoter polymorphism and stroke risk in children with sickle cell anemia. Stroke 2007;38:2241-2246.

27 Hoppe C, Klitz W, Cheng S, Apple R, Steiner L, Robles L, Girard T, Vichinsky E, Styles L: Gene interactions and stroke risk in children with sickle cell anemia. Blood 2004;103:2391-2396.
28 Imura A, Tsuji Y, Murata M, Maeda R, Kubota K, Iwano A, Obuse C, Togashi K, Tominaga M, Kita N, Tomiyama K, Iijima J, Nabeshima Y, Fujioka M, Asato R, Tanaka S, Kojima K, Ito J, Nozaki K, Hashimoto N, Ito T, Nishio T, Uchiyama T, Fujimori T, Nabeshima Y: alpha-Klotho as a regulator of calcium homeostasis. Science 2007;316:1615-1618.

29 Files B, Brambilla D, Kutlar A, Miller S, Vichinsky E, Wang W, Granger S, Adams RJ: Longitudinal changes in ferritin during chronic transfusion: a report from the Stroke Prevention Trial in Sickle Cell Anemia (STOP). J Pediatr Hematol Oncol 2002;24: 284-290.

30 Baldwin C, Nolan VG, Wyszynski DF, Ma QL, Sebastiani P, Embury SH, Bisbee A, Farrell J, Farrer L, Steinberg MH: Association of klotho, bone morphogenic protein 6 , and annexin $\mathrm{A} 2$ polymorphisms with sickle cell osteonecrosis. Blood 2005;106: 372-375.

31 Sebastiani P, Nolan VG, Baldwin CT, Abad-Grau MM, Wang L, Adewoye AH, McMahon LC, Farrer LA, Taylor JG, Kato GJ, Gladwin MT, Steinberg MH: A network model to predict the risk of death in sickle cell disease. Blood 2007;110:2727-2735.

32 Kozanoglu I, Boga C, Ozdogu H, Sezgin N, Kizilkilic E, Kural M: Automated red cell exchange procedures in patients with sickle cell disease. Transfus Apher Sci 2007;36:305-312. 